\title{
Barrios en guerra. Medellín
}

La muerte de Pablo Emilio Escobar Gaviria en 1993 a mano de las autoridades de la República de Colombia, solo cesó transitoriamente la violencia producida por el cartel de Medellín, ya que después de su deceso varios de sus lugar terratenientes continuaron de manera sucesiva toda la cadena de producción y tráfico de cocaína, generándose nuevas estructuras criminales que reemplazaron el Cartel de Medellín; entre ellas la denominada Oficina de Envigado, bajo el mando de Diego Fernando Murillo alias Don Berna, quien logró unir los grupos delincuenciales denominados "combos" retomando las prácticas sangrientas y terroríficas de los grandes narcotraficantes, consolidando así el poder de las temida estructura criminal bajo la bandera de las autodefensas.

Sin embargo, después que las Autodefensas Unidas por Colombia (AUC) se desmovilizaron en el 2006, y Don Berna fuera extraditado a Estados Unidos dos años más tarde, la Oficina de Envigado se fracturó, generándose nuevamente una atomización de grupos delincuenciales que delinquían antes de la asociación criminal construida por Diego Fernando Murillo.

El auge de los combos en Medellín, es la herencia dejada por Pablo Escobar Gaviria y posteriormente la ausencia visible de un sucesor de Don Berna para controlar la asociación Criminal que él mismo conformó después del debilitamiento del Cartel de Medellín; estos grupos están compuestos por menores entre los 14 y 15 años de edad y jóvenes entre los 18 y 25, quienes son contratados por mafias u oficinas de cobro para cometer asesinatos, son grupos que a la vez controlan territorialmente sectores en los barrios más paupérrimos de la sociedad Paisa denominadas "comunas", a través de fronteras invisibles.

El documental de Discovery Channel, nos relata también la historia de un ex integrante de los denominados combos, presentado paralelamente entrevistas a las autoridades, profesionales en diversas áreas y demás representantes de la sociedad civil que analizan la problemática social, frente a la violencia que nuevamente está viviendo la ciudad de Medellín (Colombia), a causa de los combos, quienes extorsionan y se lucran de manera exorbitante a través de las rentas que le generan el micro tráfico en las comunas de Medellín. 


\section{CINE}

El documental presenta un referente de la evolución de estos grupos y provoca la reflexión acerca de que no bastan las acciones de fuerza por parte del Estado para desintegrar a dichas agrupaciones criminales, sino que también se requiere de acciones mucho más integrales y de encontrar alternativas para los menores y jóvenes que a muy temprana edad engrosan las filas de los combos al servicio de las mafias de Medellín.

La pseudo autoridad promovida por los combos en las comunas de Medellín, donde a partir de la violencia fomentan el terror en el marco de sus fronteras invisibles, cometiendo extorsión, asesinatos y el micro tráfico de droga; exige de la autoridad la recuperación del control territorial y el apalancamiento de estrategias sociales que impacten los núcleos familiares de las personas que habitan en dichas comunas, de lo contrario, como ha sucedido en las décadas anteriores, la herencia de la violencia seguirá posicionándose en las nuevas generaciones, haciéndose cada vez más complejo el problema social de Medellín.

Sinopsis a cargo de Ribelino Sánchez Sierra

Mayor de la Policía Nacional de Colombia 